\title{
PROFIL BATIMETRI HABITAT PEMIJAHAN IKAN TERUMBU HASIL INTEGRASI DATA INDERAJA SATELIT DAN AKUSTIK: Studi Kasus Perairan Sekitar Pulau Panggang, Kepulauan Seribu
}

\author{
(COUPLING OPTIC-ACOUSTIC REMOTE SENSING FOR BATHYMETRIC \\ PROFILING OF REEF FISH SP AWNING HABITAT: Case Study of Panggang Island \\ Waters, Kepulauan Seribu)
}

\author{
Syamsul B. Agus ${ }^{12}$, Vincentius P. Siregar ${ }^{3}$, Dietriech G Bengen ${ }^{3}$, Aryo Hanggono 4 \\ 1 Corresponding author \\ ${ }^{2}$ Mahasiswa Mayor Teknologi Kelautan, Sekolah Pascasarjana IPB \\ E-mail:mycacul@gmail.com \\ ${ }^{3}$ Departemen Ilmu dan Teknologi Kelautan, FPIK IPB \\ ${ }^{4}$ Balitbang Kelautan dan Perikanan, KKP
}

\begin{abstract}
Remote sensing technology, both optic and acoustic, serves as major tool for mapping bathymetry synoptically and efficiently. In complex coral cays as Kepulauan Seribu, batbymetric profile may change gradually due to naturally controlled reef accretion/erotion, sand/coral exploitation activities, storms, and mostly several types of fishing techniques (muroami and blast fishing). In this paper, elaboration on bathymetric profiles originated from coupled optic-acoustic dataset will be applied in account for understanding reef fish spawning habitats. A total of 17 reef sites were surveyed in situ to record reef fish with spawning cues (eg: female gravid, male change color, aggregation, etc) in between October 2010-March 2012. A 2008 Quickbird imagery and single beam acoustic data were gridded at $1 \mathrm{~m}$ by interpolation using Inverse Distance to Power method resulted in 2-dimension and 3-dimension bathymetric maps thus revealing complex detail of seabed at shallow and deeper depths. Terrain profiles depicting lateral view of bathymetric profile for each reef site were used to describe geomorpological features supporting its role as spawning habitat.
\end{abstract}

Keywords: Bathymetry, remote sensing, reef fish, spawning habitat, geomorphology

\begin{abstract}
ABSTRAK
Teknologi penginderaan jauh, optik maupun akustik, berperan sebagai perangkat utama dalam memetakan kondisi batimetri secara sinoptik dan efisien. Di perairan Kepulauan Seribu yang kompleks, profil batimetri dapat berubah akibat proses alami seperti akresi/erosi terumbu oleh biota karang/ikan dan badai, maupun akibat kegiatan manusia seperti eksploitasi pasir/karang dan penangkapan ikan (menggunakan muroami dan bom). Dalam tulisan ini, elaborasi profil batimetri di perairan sekitar Pulau Panggang akan didasari oleh kombinasi set data inderaja optik-akustik untuk mengeksplorasi habitat pemijahan ikan terumbu. Sebanyak 17 stasiun telah disurvei untuk mengamati tanda pemijahan dan ikan terumbu yang terkait (misalnya: ikan betina gravid, perubahan warna pada ikan jantan, agregasi, dll) selama periode Oktober 2010Maret 2012. Citra Quickbird 2008 dan data akustik bim tunggal dikonversi dalam format raster berukuran grid $1 \mathrm{~m}$ menggunakan teknik interpolasi Inverse Distance to Power untuk menghasilkan peta batimetri 2-dimensi dan 3-dimensi yang menggambarkan kondisi dasar perairan laut dangkal. Profil terrain (kemiringan lereng) menggambarkan kondisi lateral batimetri untuk setiap lokasi yang menunjukkan tanda pemijahan ikan terumbu.
\end{abstract}

Kata Kunci : Batimetri, inderaja, ikan terumbu, habitat pemijahan, geomorfologi

\section{PENDAhUluan}

Batimetri merupakan informasi mendasar yang utamanya diperlukan dalam pemetaan laut dan kajian oseanografi sebagai referensi utama, namun pemahaman manusia terhadap kondisi dasar perairan laut di bumi lebih tertinggal dibandingkan informasi mengenai permukaan bulan atau Planet Mars sekalipun. Aplikasi lanjutan dari informasi batimetri dalam bentuk peta ataupun metadata dapat digunakan di bidang pelayaran dan membangun model oseanografi, khususnya dinamika gerak arus. Di bidang pengelolaan dan konservasi sumberdaya atau lingkungan laut, data batimetri yang diintegrasikan dengan informasi atribut tertentu, seperti sebaran spesies langka, kondisi terumbu karang, atau fenomena ekologis penting seperti habitat pemijahan ikan terumbu, dapat digunakan untuk merancang jejaring kawasan perlindungan laut 
(network of marine protected areas) yang sangat diperlukan dalam konservasi terumbu karang (Mora, 2002).

Habitat pemijahan ikan terumbu ditengarai mengalami penurunan kualitas dan kuantitas di seluruh dunia (Sadovy et al. 2012), karena secara naluri nelayan menggunakan area terumbu karang yang dijadikan habitat ikan target tangkapan untuk memijah sebagai fishing ground. Mayoritas ikan terumbu memiliki tingkah laku reproduksi untuk memijah secara berkelompok pada periode dan di lokasi terumbu karang yang spesifik (Heyman et al. 2008). Domeier and Colin (1997) membagi dua kategori habitat pemijahan ikan terumbu yaitu residen, yang umum digunakan oleh ikan predator terumbu karang dan merupakan target tangkapan nelayan, serta yang bersifat permanen, yang umum digunakan oleh ikan herbivora dan mayoritas taksa ikan terumbu lainnya.

Kajian dan monitoring in situ mengenai proses pemijahan dan eksplorasi habitat pemijahan memerlukan upaya yang persisten secara periodik. Fungsi ekologi terumbu karang sebagai habitat pemijahan agregasi ikan terumbu, khususnya habitat pemijahan transien, semakin pupus seiring kondisi terumbu karang yang mayoritas rusak. Sebagian wilayah Kepulauan Seribu telah ditetapkan sebagai kawasan Taman Nasional Laut, namun aktivitas pengrusakan tetap berlangsung tanpa dapat dicegah aparat terkait. Seiring dengan pemekaran wilayah Kepulauan Seribu sebagai Kabupaten Administratif dan mengemukanya urgensi pengelolaan berbasis masyarakat yang telah diterapkan di sejumlah pesisir dan pulau kecil Indonesia, maka sejak tahun 2004 telah digagas dan diberlakukan mekanisme konservasi terumbu karang secara bottom up, yaitu Area Perlindungan Laut-Berbasis Masyarakat di sejumlah kelurahan di Kepulauan Seribu.

Dalam penetapan zonasi, khususnya zona larang tangkap yang melarang aktivitas ekstraktif di dalamnya, diperlukan informasi mengenai proses ekologis dan habitat kunci yang berperan menjaga stabilitas stok perikanan terumbu. Tidak seluruh wilayah terumbu karang berperan sebagai habitat pemijahan, sehingga diutamakan upaya mendelineasi kawasan terumbu yang menjadi habitat pemijahan atau menunjukkan tandatanda pemijahan bagi spesies-spesies penting. Diperlukan pula informasi keruangan (geospasial) yang dapat digunakan untuk menguraikan karakteristik dasar suatu wilayah terumbu berperan sebagai habitat pemijahan, sehingga variabel-variabel geospasial tertentu yang ditengarai mencirikan habitat pemijahan dapat diterapkan di wilayah terumbu karang lain di perairan nusantara. Tujuan penulisan makalah ini adalah untuk memetakan kondisi batimetri habitat pemijahan ikan terumbu di kawasan Pulau Panggang dan sekitarnya, berdasarkan integrasi data inderaja satelit Quickbird dan pemeruman data akustik bim tunggal.

\section{METODOLOGI}

\subsection{Waktu dan Tempat}

Kegiatan pengambilan data penelitian difokuskan di wilayah perairan sekitar Pulau Panggang, Pulau Karya dan Pulau Pramuka, Kepulauan Seribu, yang dibatasi oleh koordinat $5^{\circ} 43^{\prime} 44.485^{\prime \prime}$ $5^{\circ} 45^{\prime} 17.084^{\prime \prime}$ LS dan 106 34'48.297"106³7'19.743" BT (Gambar 1). Kegiatan pengambilan data akustik dilakukan pada Februari-Maret 2012. Pengamatan tanda dan kegiatan pemijahan ikan terumbu dilakukan mulai September 2010 hingga Maret 2012, di sejumlah 17 stasiun pengamatan di daerah penelitian. Pengolahan dan analisis data dilakukan di Bagian Inderaja dan SIG Kelautan, FPIK-IPB serta Laboratory for Remote Sensing and Ecology, SEAMEO-Biotrop.

\subsection{Bahan dan Alat Penelitian}

Bahan utama yang digunakan dalam penelitian ini adalah data batimetri hasil pemeruman inderaja akustik dan data inderaja satelit Quickbird (tanggal akuisisi 28 September 2008) yang dikombinasikan dalam format raster. Peralatan utama yang digunakan untuk mendapatkan, mengolah, dan mengolah set data batimetri disajikan pada Tabel 1 . 


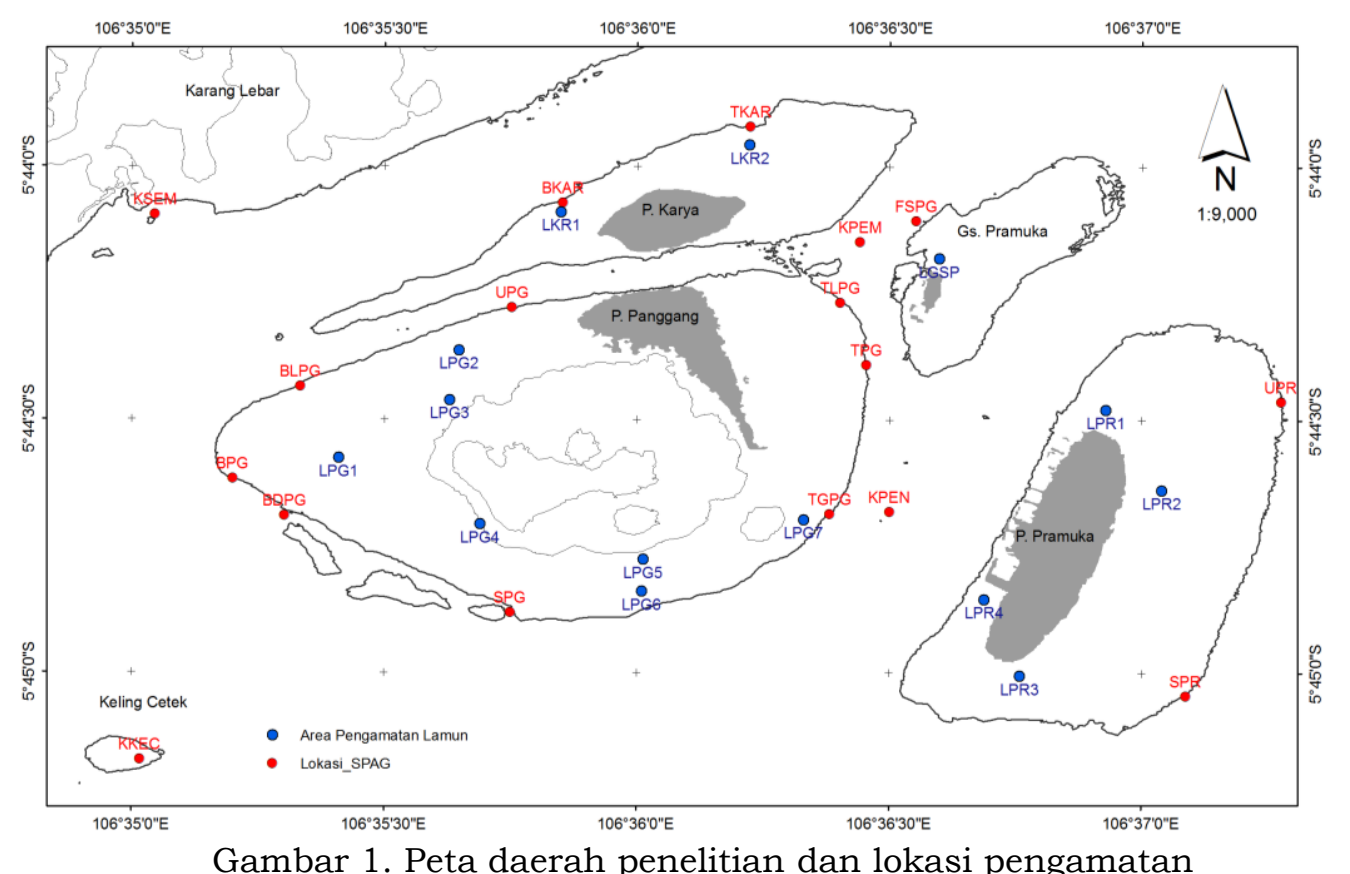

Tabel 1. Piranti keras dan lunak yang digunakan

\begin{tabular}{|l|l|l|}
\hline No & \multicolumn{1}{|c|}{ Nama piranti } & \multicolumn{1}{c|}{ Spesifikasi/Kegunaan } \\
\hline 1 & Garmin GPSMap Sounder 585 & Bim tunggal Frekuensi 50/200 Hz \\
\hline 2 & Memory card & $4 \mathrm{~GB} /$ penyimpanan data \\
\hline 3 & Kapal & Kayu, lunas tempel \\
\hline 4 & ESRI ${ }^{\circ}$ ArcGISTM versi 9.x & $\begin{array}{l}\text { Extension: Spatial Analyst, Benthic } \\
\text { Terrain Modeler }\end{array}$ \\
\hline 5 & MapSource versi 9.0 & $\begin{array}{l}\text { Untuk impor data dari Map Sounder } \\
\text { menjadi *xls, *.srf }\end{array}$ \\
\hline 6 & Surfer versi 11.0 & $\begin{array}{l}\text { Untuk interpolasi batimetri terhadap } \\
\text { hasil koreksi pasut }\end{array}$ \\
\hline 7 & MS Excel & $\begin{array}{l}\text { Untuk koreksi data kedalaman } \\
\text { terhadap pasut dan tabulasi set data }\end{array}$ \\
\hline 8 & Data pasang surut & $\begin{array}{l}\text { Untuk koreksi data kedalaman } \\
\text { terhadap variasi pasut }\end{array}$ \\
\hline
\end{tabular}

\subsection{Pengambilan data akustik}

Pemeruman kondisi dasar perairan terumbu dilakukan menggunakan alat Garmin GPSMap Sounder 585. Transduser untuk pemeruman dioperasikan pada frekuensi $50 \mathrm{kHz}$ dengan daya $500 \mathrm{~W}$, dan dipasang di sisi kiri kapal pada kedalaman $\pm 50 \mathrm{~cm}$ dari permukaan laut. Instalasi tersebut ditujukan untuk meminimalkan derau (noise) yang mungkin ditimbulkan akibat perputaran baling-baling kapal motor yang rotasinya berlawanan dengan arah jarum jam.
Set data inderaja akustik diperoleh dengan mengoperasikan GPSMap Sounder secara kontinu sepanjang transek pada kecepatan kapal \pm 5 knot. Pulsa energi suara yang dipancarkan transduser piranti keras tersebut dapat digunakan secara simultan untuk mengetahui profil dasar laut bersamaan dengan mengukur densitas ikan di kolom perairan (fish finder). Hamburan balik sinyal suara yang dipindai oleh receivertransduser menandai nilai kedalaman (z) pada titik yang telah diketahui referensi geografisnya $(\mathrm{x}, \mathrm{y})$ oleh GPS receiver (Gambar 2). 
Jalur transek dan titik kontrol pemeruman ditetapkan untuk bisa mencakup domain spasial daerah penelitian dengan tingkat kedetailan yang memadai. Jarak antar jalur transek pemeruman berkisar antara 100-200 m. Konsistensi jarak antar jalur pemeruman sulit dilakukan karena kondisi perairan yang ramai oleh kapal nelayan, kapal wisatawan, keramba, maupun struktur apung lain. Referensi spasial seluruh titik kontrol dan jalur transek direkam dalam kartu memori, sebelum diolah dan dianalisis lebih lanjut. Gambar 3 menunjukkan jalur transek yang digunakan dalam pemeruman kondisi dasar perairan terumbu.

\subsection{Pengamatan tanda dan kegiatan pemijahan ikan terumbu}

Survei visual dan transek pengamatan tanda/kegiatan pemijahan ikan terumbu dilakukan dengan modifikasi minor dari metode SCRFA dan TNC. Penyelam menyelusuri kontur lereng terumbu hingga mendekati dasar perairan terumbu, seraya mengamati kondisi sekitar dengan kekhususan menilik celah antar karang atau ceruk terumbu yang biasa menjadi habitat perlindungan ikan terumbu betina yang gravid. Selama penyelaman mengikuti jalur pengamatan yang ditetapkan, pengamat mencatat jenis ikan dan tingkah laku ikan terumbu yang memiliki tanda pemijahan. Setelah penyelaman selesai dilakukan (surfacing), referensi geografis dimarka kembali untuk mengetahui panjang transek pengamatan pemijahan.

\subsection{Analisis data geospasial Pengolahan data akustik}

Karakteristik dasar perairan terumbu di sekitar Pulau Panggang, Karya, dan Pramuka diperoleh dari kompilasi pengolahan datum (titik pemeruman yang tetap) yang menunjukkan data referensi geografis ( $\mathrm{x}$, y) dan kedalaman (z). Data terekam dalam kartu memori yang disematkan dalam Garmin GPSMap Sounder 585, kemudian ditabulasikan menggunakan MS Excel dan diolah menggunakan Surfer. Nilai kedalaman (z) dikoreksi sesuai kondisi pasang-surut saat pemeruman berlangsung, dengan rumus:

$$
F K=\frac{A}{B} x C
$$

Dimana:

$\mathrm{FK}=$ Faktor koreksi; $\mathrm{A}=$ Selisih waktu (dalam menit) antara waktu pengukuran kedalaman terhadap pukul 10:00 WIB; $\mathrm{B}=60$ menit; $\mathrm{C}=$ Selisih kedalaman (dalam meter) antara waktu pengukuran kedalaman terhadap pukul 10:00 WIB.

Visualisasi batimetri, baik secara 2dimensi maupun 3-dimensi, diperoleh menggunakan metode interpolasi inverse distance to a power (IDP) yang terdapat di perangkat lunak Surfer. Interpolasi data spasial diperlukan dalam upaya memvisualisasikan kerumitan bentang alam maupun dasar laut, karena bentukan permukaan secara spasial umumnya diperoleh dari datum yang sifatnya titik. IDP mendasari perhitungan nilai di titik yang tidak diukur menggunakan kombinasi linier dari sejumlah titik ukur yang dipengaruhi pembobotan jarak secara terbalik. Asumsi yang berlaku pada metode ini adalah bahwa nilai suatu titik yang diinterpolasi sangat dipengaruhi oleh titik-titik yang lebih dekat dengan titik tersebut daripada titik-titik yang letaknya lebih jauh.

Fungsi matematika dari metode IDP disajikan pada persamaan 2 berikut ini (Watson and Philip 1985):

$$
P=\frac{\sum_{j=1}^{C} \frac{\boldsymbol{P}_{j}}{v_{i j}^{g}}}{\sum_{j=1}^{C} \frac{1}{\left(v_{i j}^{g}\right)^{g}}} \ldots \ldots \ldots \ldots \ldots \ldots \ldots \ldots \ldots
$$

Dimana:

$\mathrm{P}=$ nilai titik grid interpolasi, $\mathrm{P}_{\mathrm{j}}=$ titik data yang berada di sekitar titik interpolasi, $D_{i j} \mathbf{n}=$ jarak antara titik grid dengan titik data yang akan diinterpolasi, $\mathrm{G}=$ total datum yang digunakan untuk interpolasi, dan $\beta=$ nilai pembobotan (sebagai fungsi jarak atau kemiringan). 

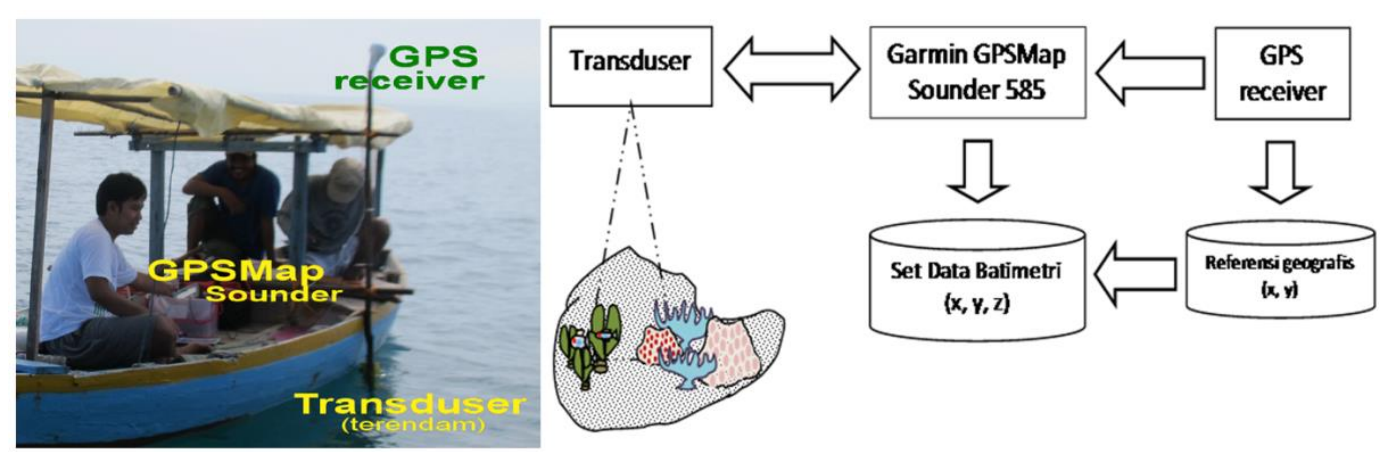

Gambar 2. Ilustrasi dan diagram alir pemeruman kondisi batimetri

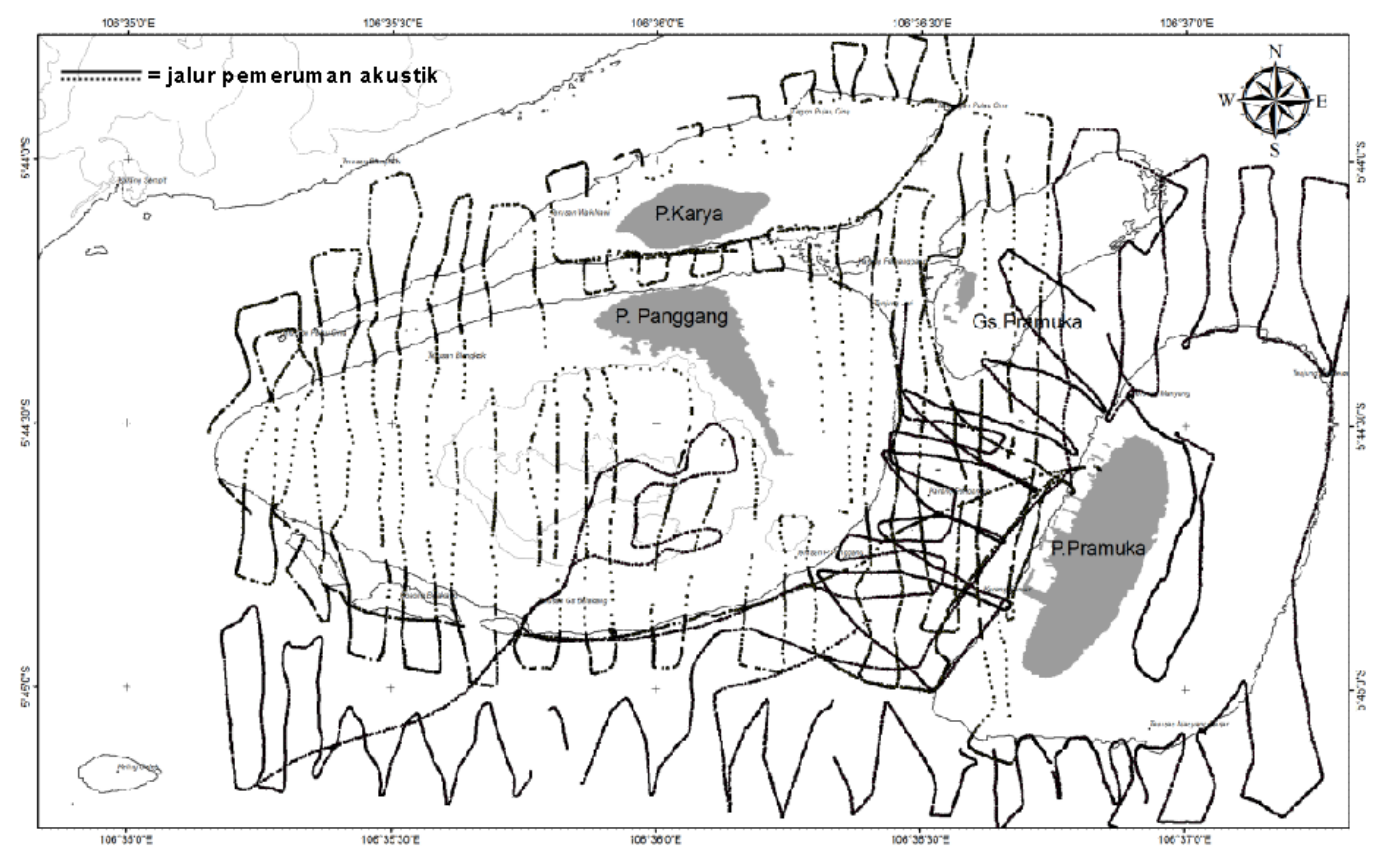

Gambar 3. Jalur transek pemeruman kondisi batimetri

\section{Pengolahan data satelit}

Data inderaja satelit Quickbird terdiri atas empat kanal spektra yaitu kanal biru, hijau, merah dan infra merah, yang beroperasi pada nilai tengah panjang gelombang $479,5 \mathrm{~nm}, 546,5 \mathrm{~nm}$, $654 \mathrm{~nm}$, dan 814,5 nm. Penyusunan profil batimetri dari citra Quickbird dilakukan menggunakan algoritma Lyzenga (1985), yang secara matematis dinyatakan sebagai berikut (Persamaan 3):

$Z=-\left(\frac{1}{2} k * \ln \left(V-V_{s}\right)\right)+\left(\frac{1}{2} k *\left(\ln V_{0}\right)\right)$.

dimana:

$Z=$ kedalaman $(\mathrm{m}) ; \quad V=$ sinyal radians yang diamati pada citra Quickbird; $V_{S}=$ bagian sinyal yang dihasilkan oleh pembauran radiasi di atmosfir, kolom air, dan permukaan laut; $k=$ koefisien atenuasi; dan $V_{o}=$ faktor sensitifitas yang meliputi kontribusi iradiansi elektromagnetik di permukaan air, pantulan dasar perairan, transmisi atmosfir dan pengaruh sensor satelit sendiri.

Didasari asumsi bahwa nilai radiansi (V) bervariasi terhadap kedalaman, maka persamaan logaritmik dapat diubah sesuai menjadi bentuk linier. Hal tersebut diawali dengan penetapan asumsi bahwa wilayah perairan dalam (dengan nilai kedalaman $>30-40$ meter) memiliki nilai radiansi $=0$, karena spektrum energi warna biru telah terserap habis di sepanjang kolom perairan dan tidak sempat mencapai dasar. Persamaan (3) selanjutnya diganti menjadi persamaan (4) berikut:

$Z=a X+b$.

dimana: 
$Z=$ kedalaman $(\mathrm{m})$;

$a=$ sudut kemiringan $\left(\frac{1}{2} k\right)$;

$X=\ln \left(V-V_{S}\right) ; \quad b=\frac{1}{2} k *\left(\ln V_{0}\right)$

\section{HASIL DAN PEMBAHASAN}

\subsection{Hasil}

\subsubsection{Profil batimetri hasil integrasi} inderaja satelit dan akustik

Gambar 4 menunjukkan profil batimetri daerah penelitian secara 2 dimensi. Profil batimetri disusun berdasarkan data satelit inderaja dan hasil pemeruman akustik yang diintegrasikan sehingga dengan metode interpolasi. Proses resample grid dibuat berdasarkan grid cell 1x1 meter. Kontur kedalaman yang rumit umumnya dijumpai di sekeliling beting terumbu yang mengampu dudukan pulau datar (cays), seperti Pulau Karya, Gosong Pramuka, Pulau Panggang, dan Pulau Pramuka. Perairan Kepulauan Seribu umumnya tergolong perairan laut dangkal karena berada di Paparan Sunda (Sunda Shelf) yang rerata kedalaman maksimumnya sekitar $200 \mathrm{~m}$. Khusus untuk perairan di daerah penelitian, rerata kedalamannya adalah sekitar 15 meter.

Perairan celah antar pulau menunjukkan kontur batimetri yang terjal, sedangkan perairan di luar beting terumbu memiliki kontur yang landai. Profil lereng di beting Karang Lebar juga terlihat landai. Pemeruman bim tunggal menggunakan GPS Map Sounder Garmin 585 mendeteksi adanya pematang terumbu (ridge reef) yang tumbuh paralel terhadap beting terumbu (reef rim) Pulau Panggang. di antara Pulau Pramuka dan Pulau Panggang yang disebut sebagai Karang Pengantin (KPEN) dan menggunakan visualisasi 3-dimensi fitur tersebut lebih jelas terlihat (Gambar 5). Bentukan pematang terumbu yang memanjang dari beting di timur laut Pulau Panggang juga teramati dan biasa disebut penduduk sekitar sebagai Tanjung Jari. Dari Tanjung Jari, terdapat pematang terumbu lain yang memulai akresinya ke arah permukaan, walau baru mencapai kedalaman 27 meter dari 32 meter, yang oleh penduduk dinamakan sebagai Karang Pemanggang (KPEM).

Secara umum, batimetri daerah penelitian menunjukkan bentang rataan terumbu yang dangkal dan permukaannya cenderung rata dengan kedalaman maksimum 5 meter. Di dalam satu sistem terumbu (inner reef), yakni di Pulau Panggang, terdapat goba yang kedalaman maksimumnya mencapai 13 meter (Gambar 5). Penampang rataan terumbu umumnya membujur dari barat ke timur, rerata bentangan panjang rataan terumbu mencapai 877 meter dengan rerata lebar mencapai 358 meter.

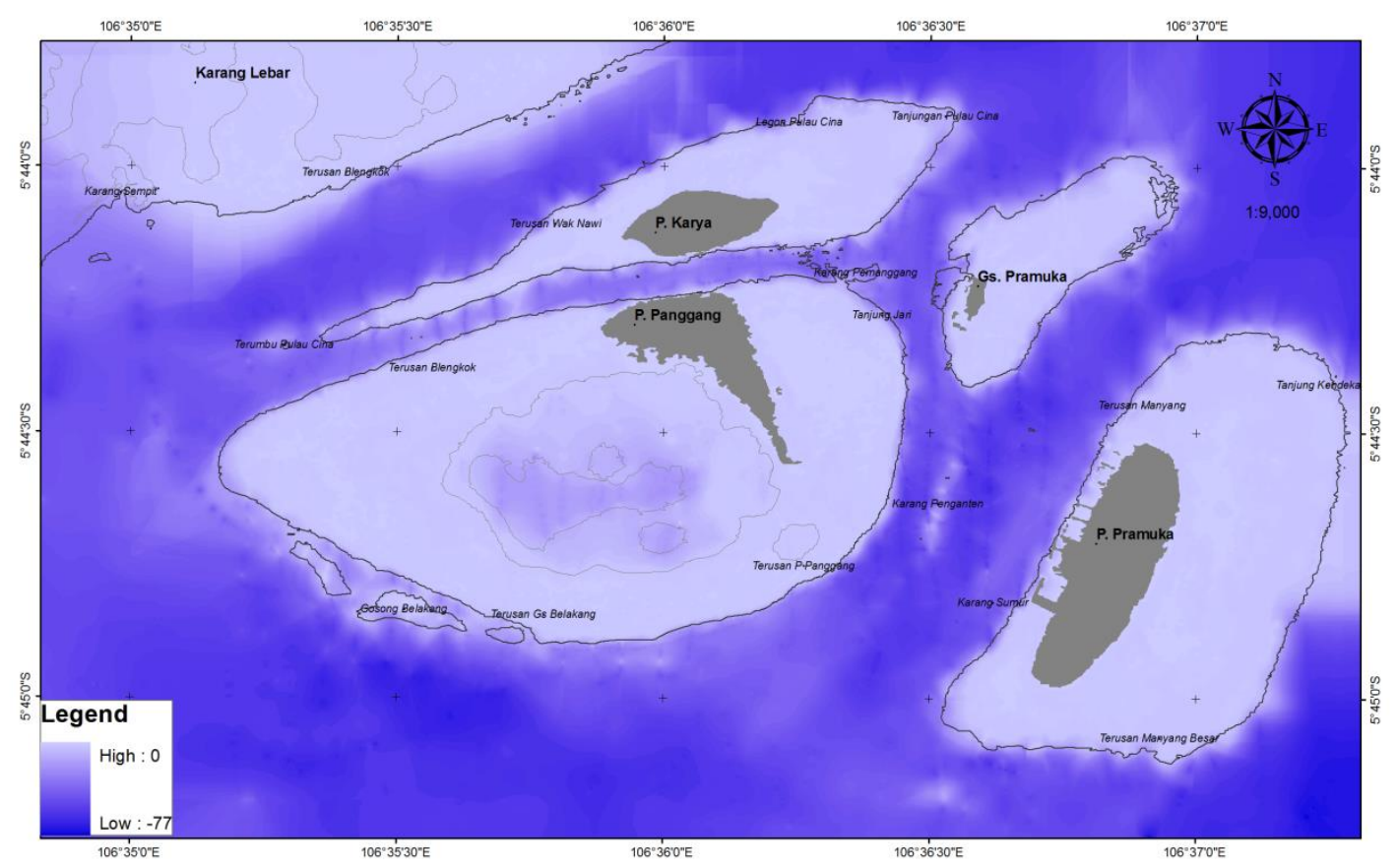

Gambar 4. Tampilan 2 dimensi profil batimetri daerah penelitian 


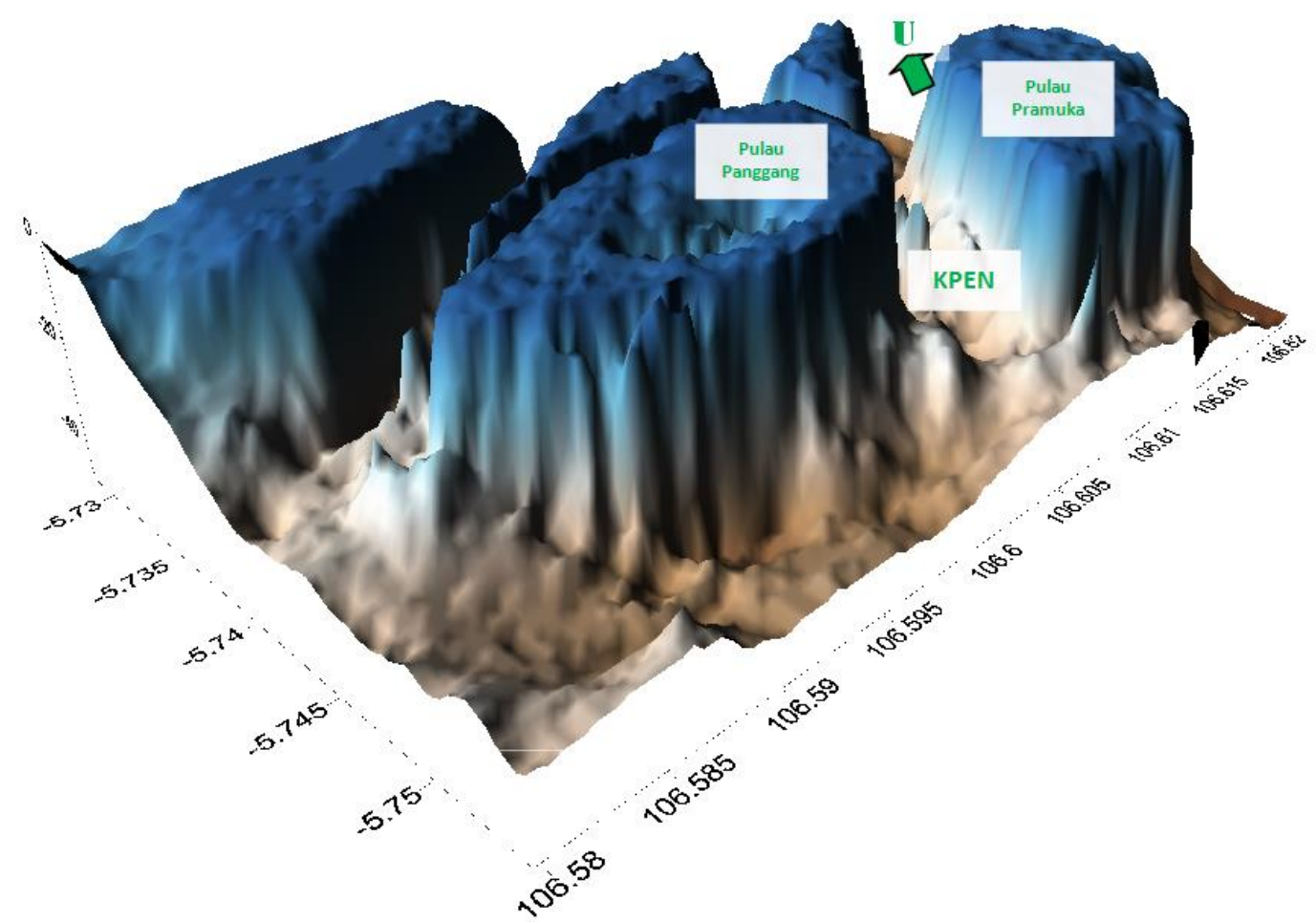

Gambar 5. Tampilan 3 dimensi profil batimetri daerah penelitian

Punggung terumbu (reef crest) membentuk beting (rim) yang mengelilingi dataran pulau (cay) pada kedalaman 01,5 meter, dengan karakteristik permukaan yang kasar akibat kombinasi bentukan koloni karang, substrat pasir, maupun pecahan karang yang kerap diterpa empasan gelombang dan arus yang pecah (breaking waves). Zona luar terumbu (outer reef atau fore reef) membentuk lereng (reef slope) yang elevasinya menurun dari punggung terumbu hingga ke kedalaman 13-32 meter.

\subsubsection{Profil pemijahan ikan terumbu}

Di sekeliling Pulau Panggang, terhampar beting terumbu yang membatasi perairan di dalam rataan terumbu dan goba (inner reef) dengan perairan di luar punggung terumbu (outer reef crest). Survei visual untuk mengamati tanda dan kegiatan pemijahan ikan terumbu dilakukan sejak Oktober 2010 hingga Maret 2012, walaupun pengamatan periodik tidak dilakukan secara konsisten sepanjang kurun waktu tersebut.

Dari sekitar 66 taksa ikan terumbu yang diamati menunjukkan tanda atau melakukan kegiatan pemijahan, uraian yang disampaikan dalam lingkup penelitian hanya dibatasi terhadap ikan target (Adrim 1997) dan ikan terumbu non-target yang teramati juvenilnya di habitat lamun. Berdasarkan ketentuan tersebut dijumpai ada 43 spesies ikan terumbu yang berasal dari 9 famili, yaitu Apogonidae (ikan sersan mayor), Haemulidae (ikan kumpele), Lethrinidae (ikan lencam), Lutjanidae (ikan kakap), Nemipteridae (ikan kurisi), Plotosidae (ikan sembilang), Scaridae (ikan kakatua), Serranidae (ikan kerapu), dan Siganidae (ikan baronang).

Tercatat sedikitnya dua tanda pemijahan di masing-masing stasiun penelitian, dari tujuh tanda pemijahan ikan terumbu yang diamati. Ketujuh tanda pemijahan ikan yang diamati adalah kondisi morfologi yang unik, seperti (1) corak atau perubahan warna pada ikan jantan dan (2) ikan betina gravid (perutnya membengkak karena mencapai Tingkat Kematangan Gonad IIIV); (3) berenang berpasangan antara ikan jantan-betina (courtship); (4) ikan betina bersembunyi atau menetap di dasar terumbu; (5) bermigrasi cepat secara berkelompok; (6) agregasi; (7) mating dan/atau spawning (pelepasan telur atau 
gamet jantan dan gamet betina di kolom air).

\subsection{Pembahasan}

Pada penelitian ini terdapat 17 stasiun pengamatan pemijahan ikan terumbu, namun profil batimetri secara detail hanya dapat ditampilkan untuk 15 stasiun pemijahan terumbu karena jalur pemeruman akustik tidak mencakup KSEM (Karang Sempit) dan KKEC (Karang Keling Cetek). Menggunakan profil melintang, batimetri dan geomorfologi dasar terumbu akan ditinjau dari perairan dangkal ke perairan yang lebih dalam. Kombinasi set data inderaja satelit Quickbird dan akustik Garmin MapSounder menunjukkan beberapa lokasi yang berperan sebagai kanal atau kaloran yang menghubungkan massa air dari dalam rataan terumbu (inner reef) ke luar (outer reef) dan sebaliknya, maupun berperan dalam mekanisme perpindahan ontogeni (ontogenetic shift).

Menggunakan profil melintang, batimetri dan geomorfologi dasar terumbu akan ditinjau dari perairan dangkal ke perairan yang lebih dalam. Sebagai acuan dalam menguraikan profil dasar terumbu, ditetapkan 20 transek yang melintang tegak lurus terhadap beting terumbu atau terhadap garis pantai terdekat. Mayoritas transek tersebut ditetapkan berdasarkan referensi geografisnya terhadap stasiun pemijahan terumbu atau stasiun juvenil lamun (jika tidak ada stasiun pemijahan terumbu di sekitar kaloran yang terdeteksi).
Dari wawancara dengan penduduk Kepulauan Seribu, diketahui istilah yang umum digunakan masyarakat setempat untuk merujuk pada lokasi kaloran. Kaloran atau reef channel merupakan fitur geomorfologi yang penting dalam proses ontogeni, karena larva ikan akan hanyut terbawa ke dalam habitat lamun yang lebih dangkal melewati wilayah tersebut. Gambar 6 menunjukkan bahwa ada enam (6) kaloran di daerah penelitian, yang oleh penduduk setempat dinamakan Terusan Blengkok dan Terusan Panggang di sekitar Pulau Panggang, Terusan Manyang dan Terusan Manyang Besar (Pulau Pramuka), serta Terusan Wak Nawi di Pulau Karya dan Terusan Blengkok di Karang Lebar.

Dari 17 stasiun penelitian terumbu karang yang ditujukan untuk mengamati aktivitas/tanda pemijahan ikan terumbu, dapat diketahui di wilayah mana saja yang memiliki spesies ikan terumbu dengan tanda pemijahan terbanyak. Secara kumulatif, ada 22 famili ikan terumbu yang menunjukkan tanda/aktivitas pemijahan di perairan terumbu karang yang menjadi daerah penelitian ini. Ke-22 famili tersebut adalah Apogonidae, Balistidae, Caesionidae, Centrisciidae, Chaetodontidae, Eceneidae, Ephippidae, Fistulariidae, Lethrinidae, Lutjanidae, Nemipteridae, Plotosidae, Pomacanthidae, Pomacentridae, Scaridae, Scorpaenidae, Serranidae, Siganidae, Syngnathidae, Synodontidae, Tetraodontidae, dan Zanclidae.

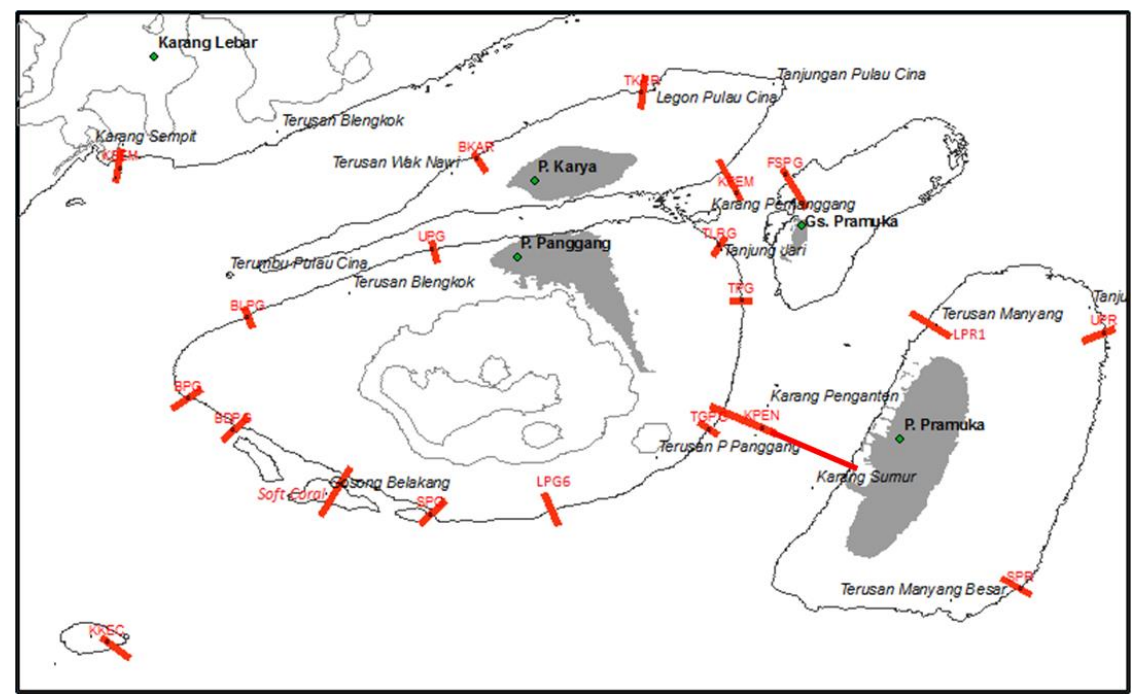

Gambar 6. Sebaran transek yang menjadi acuan transek profil batimetri melintang 


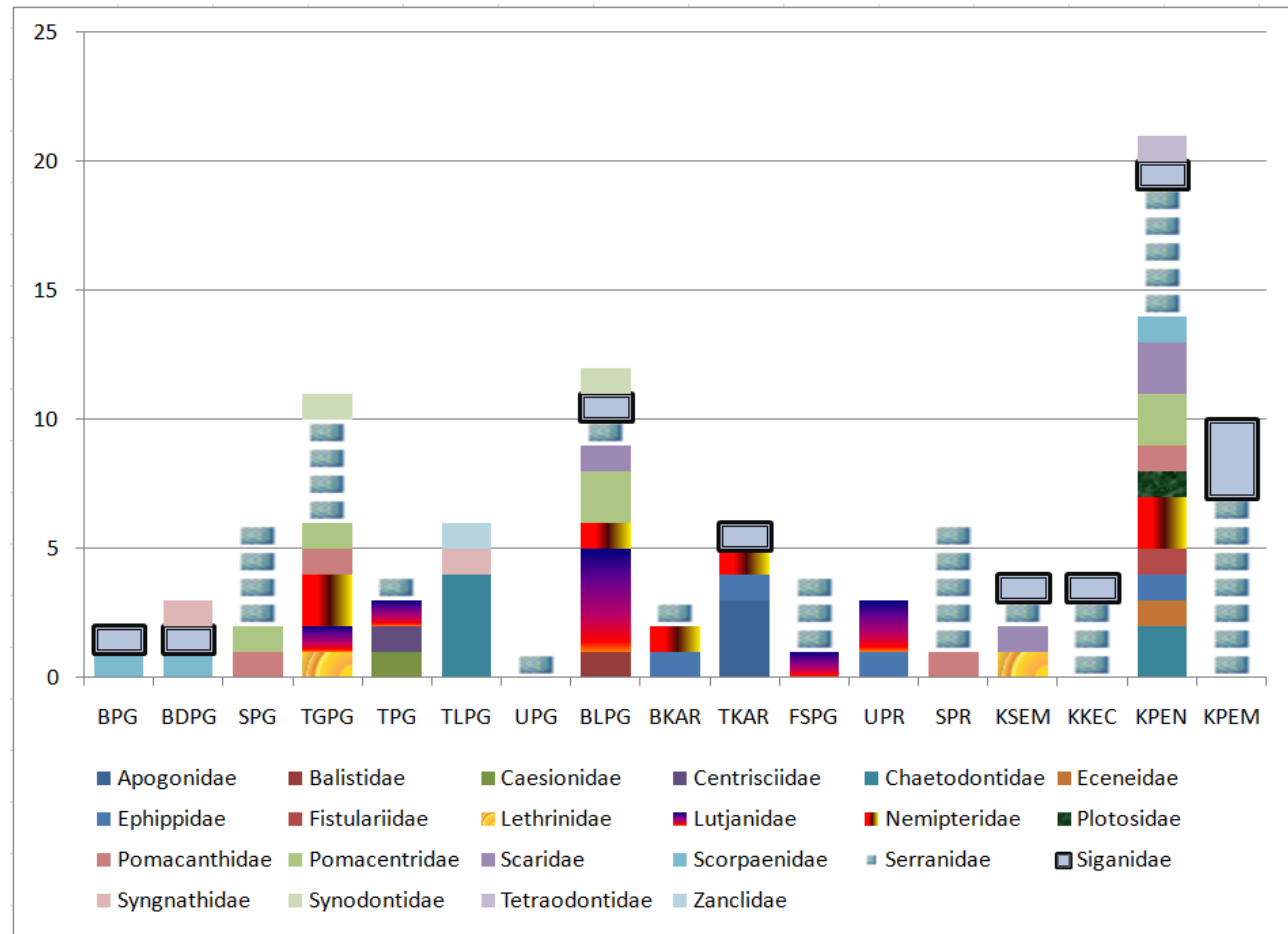

Keterangan:

$\mathrm{BPG}=$ Barat Pulau Panggang; $\mathrm{BDPG}=$ Barat Daya Pulau Panggang; $\mathrm{SPG}=$ Selatan Pulau Panggang; TGPG = Tenggara Pulau Panggang; TPG= Timur Pulau Panggang; TLPG= Timur Laut Pulau Panggang; $\mathrm{UPG}=$ Utara Pulau Panggang; BLPG= Barat Laut Pulau Pulau Panggang; BKAR= Barat Pulau Karya; TKAR= Timur Pulau Karya; FSPG= Fish Shelter APL Panggang; UPR= Utara Pulau Pramuka; SPR= Selatan Pulau Pramuka; KSEM= Karang Sempit; KKEC= Karang Keling Cetek; KPEN= Karang Pengantin; KPEM= Karang Pemanggang.

Gambar 7. Keragaan taksa menurut famili ikan terumbu yang menunjukkan tanda/aktivitas pemijahan di stasiun penelitian

Selain famili ikan terumbu yang teramati menunjukkan tanda atau melakukan aktivitas pemijahan (Gambar 7), di beberapa lokasi yaitu di BDPG, SPG, TGPG, BLPG dan FSPG dijumpai satu atau beberapa schooling larva ikan yang merupakan salah satu fase awal dalam proses ontogeni ikan terumbu.

Stasiun penelitian yang menunjukkan keragaan taksa ikan terumbu tertinggi adalah Karang Pengantin (KPEN). Stasiun penelitian yang memiliki keragaan taksa tertinggi adalah BLPG dan TGPG (14 dan 15 famili, yang keduanya diduga merupakan gerbang pintasan arus dari barat maupun dari timur daerah penelitian. Stasiun yang memiliki sedikit tanda pemijahan adalah UPG dan BPG. Mayoritas hasil pengamatan mencatat sejumlah tanda pemijahan seperti, tingkah laku bersembunyi, agregasi, morfologi unik (misalnya: bagian ventral membuncit karena matang gonad atau gravid), perubahan warna tubuh, hatching eggs, dan courtship behavior.

\subsubsection{Beting Terumbu Pulau Panggang}

Batimetri di UPG (Gambar 8 kiri atas) cukup terjal dengan kemiringan $65^{\circ}$ dari kedalaman 13 meter. Hanya ada dua famili ikan yang menunjukkan tanda pemijahan di UPG, yaitu Serranidae (Cephalopolis sonnerati) dan Caesionidae (Caesio cuning, C. xanthonota, dan Pterocaesio lativittata). Tanda pemijahan yang ada adalah perubahan warna pada jantan Caesio xanthonota dan Pterocaesio lativittata, serta kondisi gravid pada ikan betina Caesio cuning dan Cephalopolis sonnerati yang kerap bersembunyi di celah sempit pada kedalaman 7-12 meter.

Membentuk broad slope, lereng terumbu di BLPG memiliki elevasi $\pm 43^{\circ}$ menuju ke kedalaman 22 meter dan selanjutnya menjadi sangat landai dengan elevasi $\pm 43^{\circ}$ menuju kedalaman 25 meter. Lebar slope dari punggung terumbu menuju ke substrat pasir di paparan dasar laut mencapai 150 meter. Ada sembilan taksa ikan terumbu dari lima famili yang dijumpai menunjukkan 
tanda pemijahan di BLPG, yaitu Caesionidae, Lutjanidae, Scaridae, Serranidae, dan Siganidae. Dengan keragaan empat spesies, ikan kakap (Lutjanidae) merupakan taksa yang paling umum dijumpai menunjukkan tanda pemijahan berupa ikan betina gravid, kemunculan corak dan warna unik pada ikan jantan, dan perilaku courtship.
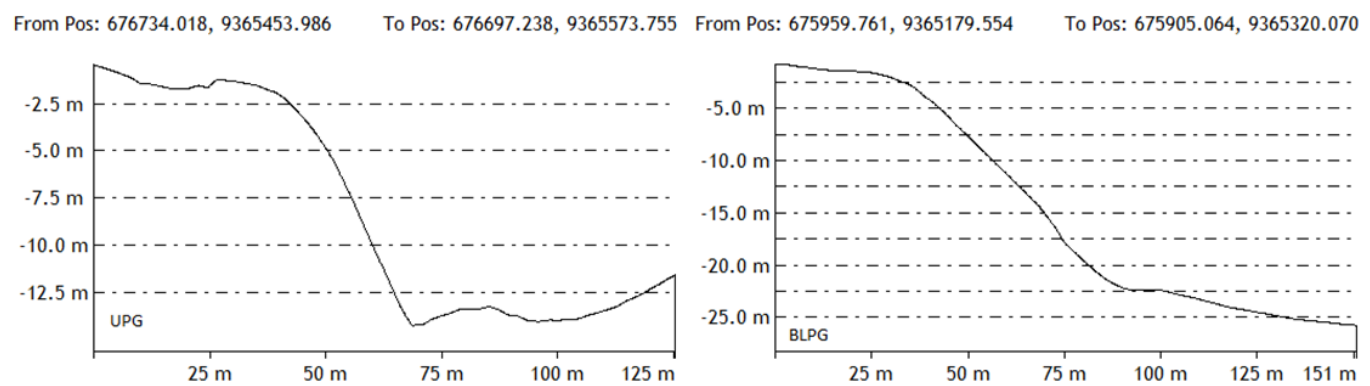

From Pos: $675758.889,9364940.015 \quad$ To Pos: $675604.226,9364826.847$
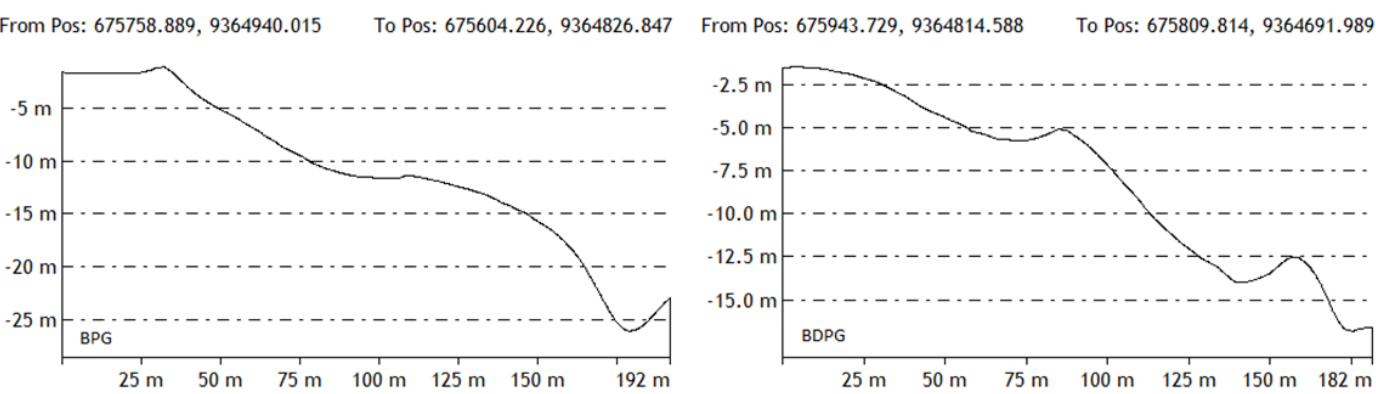

Gambar 8. Profil melintang batimetri di stasiun pemijahan terumbu (searah jarum jam dari kiri atas) Utara Pulau Panggang (UPG), Barat Laut Pulau Panggang (BLPG), Barat Daya Pulau Panggang (BDPG), dan Barat Pulau Panggang (BPG)

From Pos: $676367.166,9364604.284$ To Pos: 676241.738 , 9364397.753 From Pos: $676770.797,9364462.824 \quad$ To Pos: $676626.508,9364330.795$
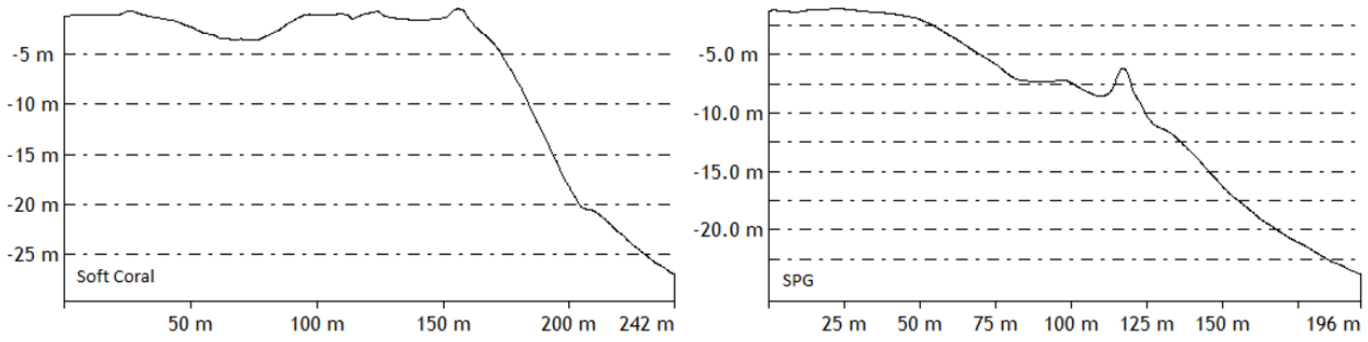

From Pos: 677180.088 , 9364491.116 To Pos: $677265.907,9364292.130$ From Pos: $677844.005,9364774.979$ To Pos: $677935.483,9364714.623$
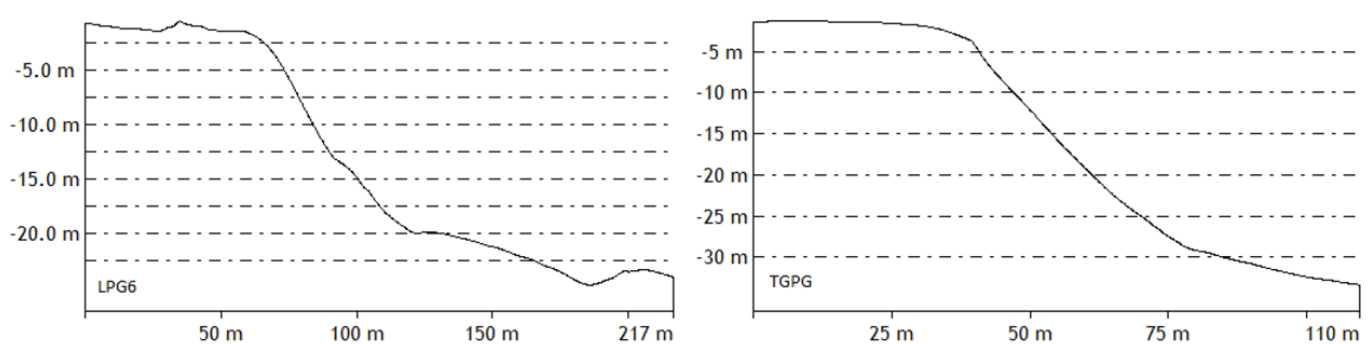

Gambar 9. Profil melintang batimetri di beting terumbu Pulau Panggang (searah jarum jam dari kiri atas) Soft Coral Garden, Selatan Pulau Panggang (SPG), Stasiun Pembesaran Lamun di Selatan Pulau Panggang (LPG6), dan Tenggara Pulau Panggang (TGPG) 
Stasiun pemijahan BPG dan BDPG tergolong broad slope dengan elevasi landai berkisar $15-40^{\circ}$, yang substrat dasarnya didominasi karang lunak (soft coral) dan pecahan karang (rubble). Tampilan batimetri 3-dimensi menunjukkan bahwa di sebelah barat masing-masing stasiun terdapat gosong terumbu (patch reefs) yang berderetan. Hanya ada satu tanda pemijahan, yaitu perubahan warna tubuh ikan jantan Famili Siganidae yang menjadi lebih gelap.

Ada dua transek yang bukan merupakan stasiun pemijahan ikan terumbu, namun ditampilkan profil melintangnya yaitu Soft Coral dan LPG6 (Gambar 10). Kedua lokasi tersebut sempat diamati pada survei pendahuluan menggunakan teknik manta tow, dan mendapati bahwa substrat bentik terumbu di kawasan barat Pulau Panggang didominasi oleh karang lunak (soft corals) dan pecahan karang batu (rubbles). Kecuali di transek Soft Coral, lereng terumbu di ketiga transek pada Gambar 9 membentuk broad slope dengan elevasi yang lebih landai $\left(5-40^{\circ}\right)$. Lereng terumbu di SPG terlihat lebih kompleks dengan adanya bentukan shelf edge diikuti dengan depression dan narrow plains pada kedalaman \pm 8 meter, selanjutnya lereng terumbu membentuk elevasi sebesar $35^{\circ}$ hingga punggung terumbu. Elevasi lereng terumbu di SPG mencapai $40^{\circ}$ dari shelf edge hingga kedalaman 25 meter, sehingga dikatakan lebih curam dibandingkan TGPG yang kisaran elevasi lerengnya berkisar 17$30^{\circ}$.
Di stasiun terumbu SPG dan TGPG dijumpai schooling larva ikan dan tanda pemijahan yang lebih marak dibandingkan stasiun lainnya. Selain perubahan morfologi pada ikan jantan dan betina, sejumlah individu ikan jantan menunjukkan perilaku yang jarang terlihat pada kurun periode lain. Perilaku khusus tersebut umumnya ditunjukkan ikan-ikan jantan Famili Caesionidae dan Serranidae, yang terlihat agresif berkompetisi memperoleh ruang dan melakukan courtship dengan ikan betina. Sebagian ikan jantan yang tersingkir dalam perebutan courtship memiliki luka di badan dan sirip dorsal atau caudalnya.

Lereng terumbu TPG termasuk yang paling curam di antara transek stasiun pemijahan terumbu lain, dengan elevasi mencapai $70^{\circ}$ (Gambar 12 kiri). Kedua stasiun, TPG dan TLPG, memiliki shelf edge yang terdapat pada kedalaman 12 meter dan 20 meter. Komunitas ikan terumbu di TLPG yang menunjukkan tanda pemijahan courtship behavior digolongkan oleh Adrim (1997) sebagai ikan mayor utama dan ikan indikator, yaitu ikan tangkur zebra (Syngnathidae) dan ikan kepe-kepe (Chaetodontidae). Di TPG dijumpai tiga (3) tanda pemijahan berupa ikan betina gravid, ikan jantan yang agresif dan menunjukkan pola warna unik, serta agregasi sebelum pemijahan berlangsung. Kecuali ikan piso-piso (Centriscidae), seluruh taksa ikan terumbu lain yang memiliki tanda pemijahan di TPG merupakan ikan target tangkapan nelayan, yaitu Caesionidae, Lutjanidae, dan Serranidae.
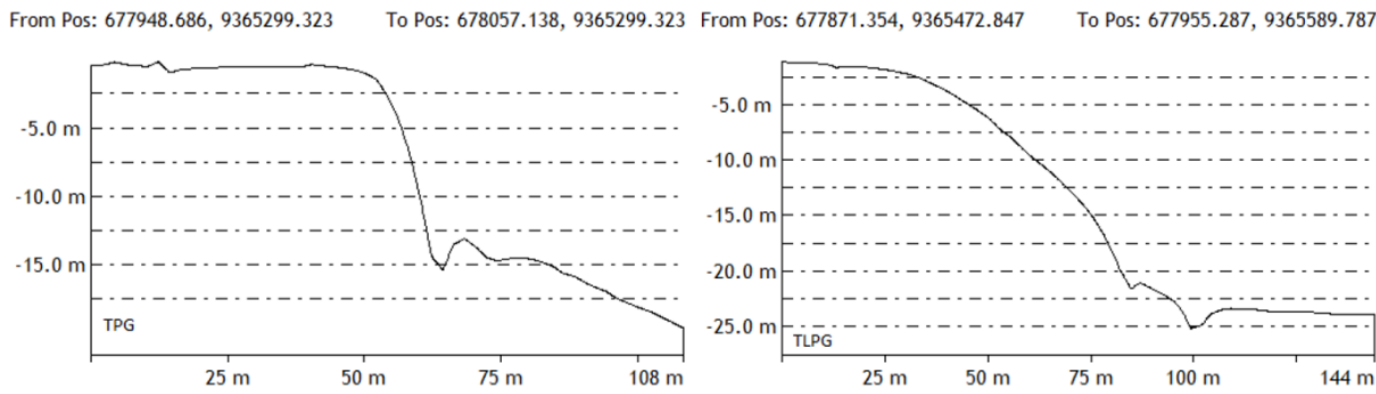

Gambar 10. Profil melintang batimetri di beting terumbu Pulau Panggang (kiri-kanan) Timur Pulau Panggang (TPG) dan Timur Laut Pulau Panggang (TLPG) 


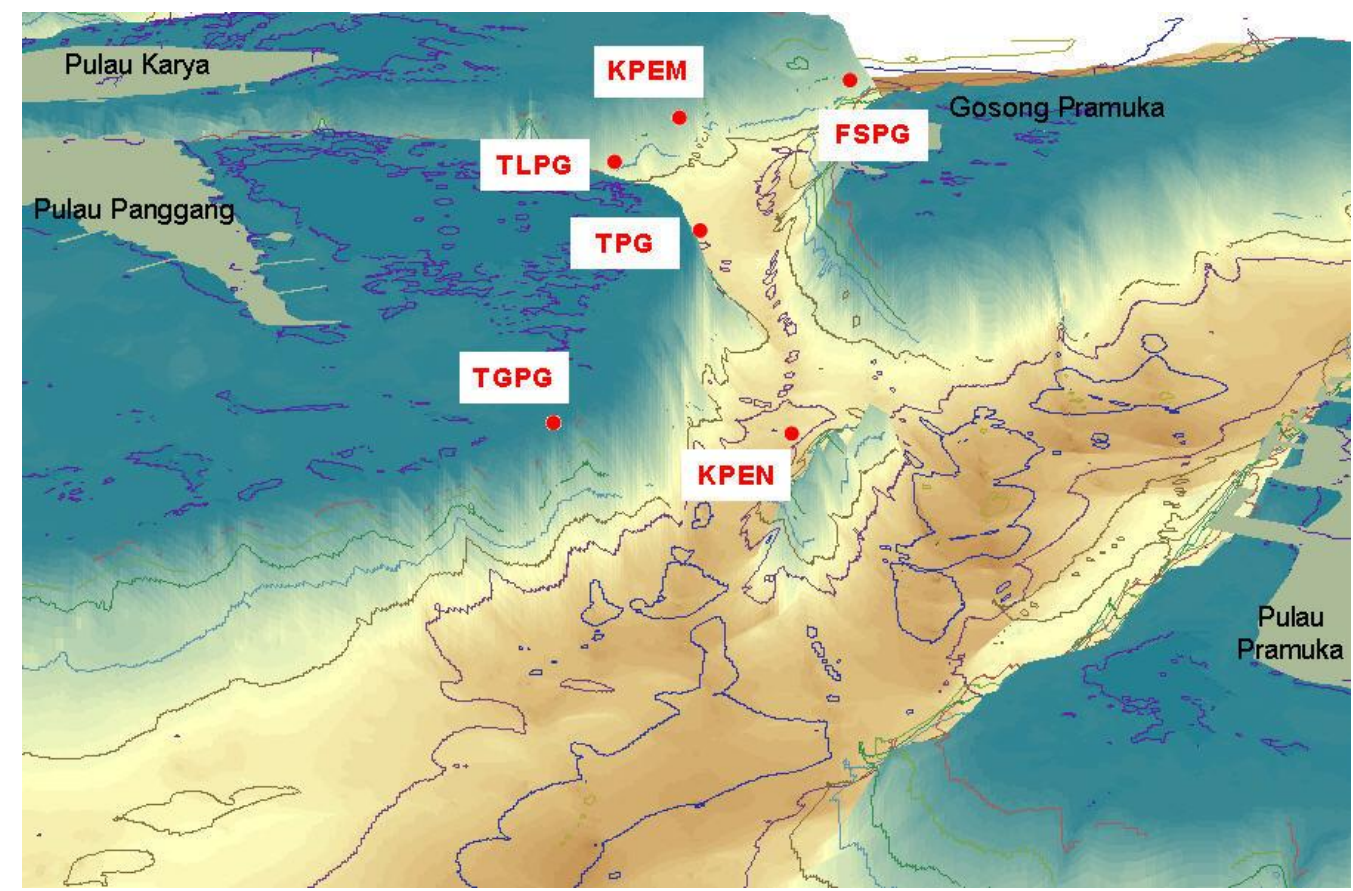

Gambar 11. Tampilan 3 dimensi profil batimetri di kawasan timur Pulau Panggang dan Karang Pengantin (KPEN)

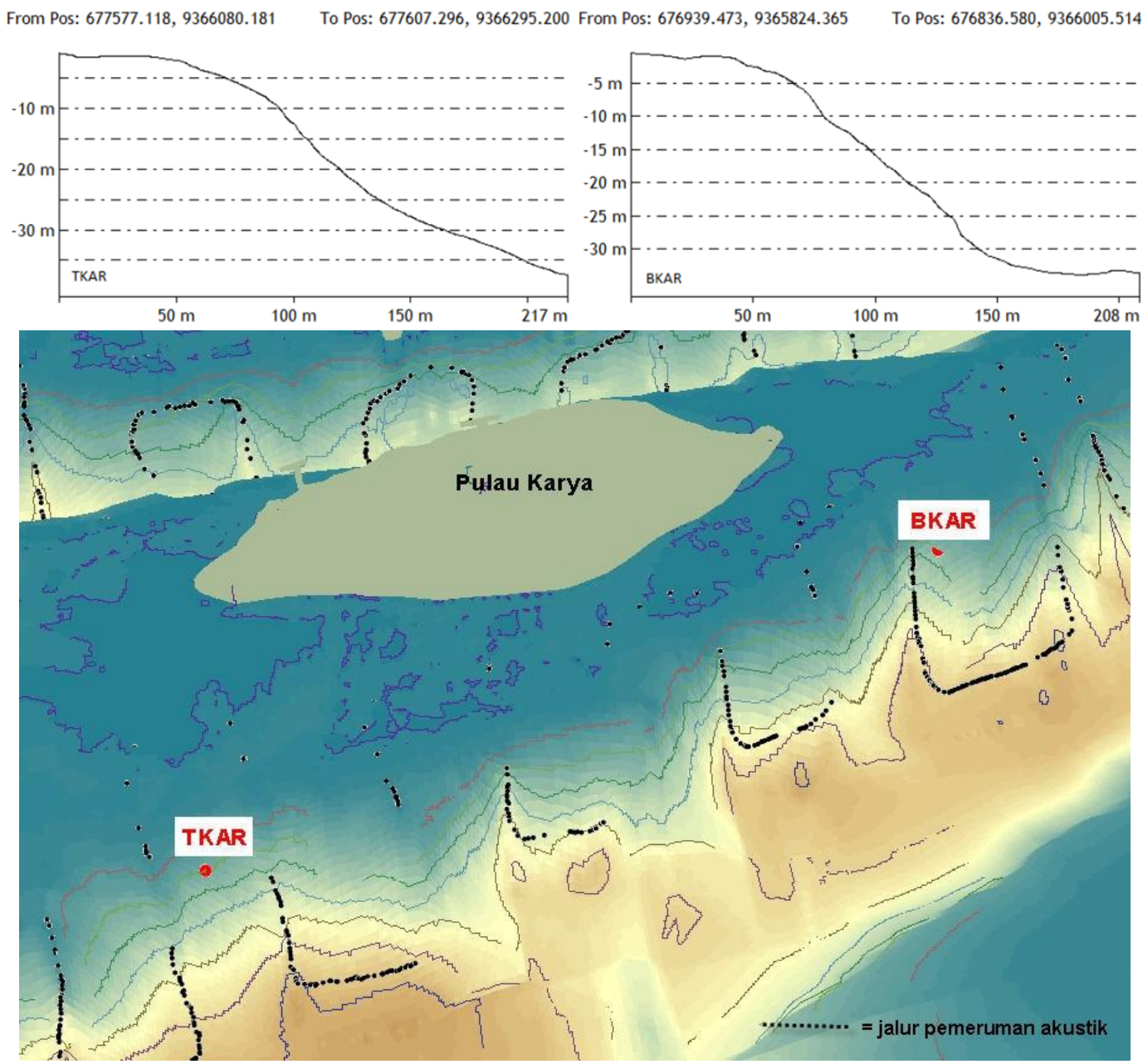

Gambar 12. Profil melintang batimetri di beting terumbu Pulau Karya: Timur Pulau Karya (kiri atas), Barat Pulau Karya (kanan atas), dan tampilan 3dimensinya (bawah) 


\subsubsection{Pulau Karya}

Pulau Karya memiliki profil lereng yang membentuk broad slope dengan lebar mencapai $150 \mathrm{~m}$ dari punggung terumbu hingga ke dasar perairan terumbu pada kedalaman $>30 \mathrm{~m}$. Profil lereng terumbu di stasiun pemijahan ikan terumbu di barat Pulau Karya (BKAR) lebih homogen dengan elevasi dari kedalaman $30 \mathrm{~m}$ yang mencapai $40^{\circ}$. Di Timur Pulau Karya (TKAR) terdapat dua profil lereng terumbu yaitu $15^{\circ}$ dari kedalaman $35 \mathrm{~m}$ menuju ke $25 \mathrm{~m}$, yang diikuti selanjutnya dengan kelerengan senilai $42^{\circ}$ hingga mencapai punggung terumbu (Gambar 12).

Tanda pemijahan yang teramati di BKAR adalah perubahan warna pada ikan jantan Caesio xanthonota (Caesionidae) dan Scolopsis monogramma (Nemipteridae), serta kondisi gravid pada ikan betina Epinephelus polylepis (Serranidae). Di TKAR terdapat lebih banyak taksa ikan terumbu dengan tanda pemijahan yang sama, yaitu tiga spesies ikan beseng (Apogonidae), Scolopsis bilineatus (Nemip-teridae), dan Siganus guttatus (Siganidae).

\subsubsection{Karang Pemanggang dan Gosong Pramuka}

Terdapat dua sistem terumbu yang kedalamannya lebih dari 15 meter di beting luar terumbu Pulau Panggang, dan salah satunya adalah Karang Pemangggang (KPEM) yang terletak di celah sempit antara Pulau Panggang, Pulau Karya dan Gosong Pramuka (Gambar 13).

Transek yang menggambarkan profil melintang batimetri di KPEM ditarik dari beting Pulau Karya yang berada di utaranya. Gambar 13 menunjukkan bahwa KPEM terdapat pada level kedalaman 25 meter dan terpisah sejauh \pm 170 meter dari punggung terumbu Pulau Karya. Kategori bentik terumbu yang umum dijumpai di KPEM adalah karang mengerak (encrusting) dan karang kompak (massive) yang koloninya terserak satu sama lain (patchy distributed). Dasar perairan di KPEM secara umum didominasi oleh pecahan karang, selain pasir, yang umumnya telah ditutupi oleh alga. KPEM memiliki kekayaan taksa ikan terumbu dengan tanda pemijahan paling tinggi, dengan dijumpai 14 spesies dari 3 famili (Caesionidae, Serranidae,
Siganidae). Diduga keberadaan fitur shelf edge di KPEM serta kemungkinan adanya pertemuan arus dari beberapa pintasan menjadikan KPEM sebagai habitat pemijahan agregasi yang bersifat residen. Heyman et al. (2008) menguraikan karakteristik geomorfologi terumbu yang menjadi habitat pemijahan agregasi ikan kakap (Lutjanidae) di Gladden Spit, Belize. Dari 6 sites yang ditetapkan sebagai habitat pemijahan, sebagian besar memiliki fitur shelf break dan berhadapan langsung dengan arah masuknya arus kuat, sedangkan yang lain berada di kanal perairan yang sempit antar pulau/sistem terumbu.

Stasiun pengamatan pemijahan FSPG berada di zona pemanfaatan Area Perlindungan Laut Kelurahan Pulau Panggang (APL Panggang). Di dasar terumbu pada kedalaman \pm 30 meter telah ditenggelamkan sejumlah modul terumbu buatan berbentuk kubus. Saat pengamatan pemijahan, dijumpai ada 5 spesies ikan terumbu dari 3 famili (Caesionidae, Haemulidae, Serranidae) dengan tanda pemijahan berupa perubahan warna (jantan) dan gravid (betina).

\subsubsection{Pulau Pramuka dan Karang Pengantin}

Terdapat dua stasiun pengamatan pemijahan di Pulau Pramuka (UPR dan SPR) dan empat stasiun pengamatan juvenil lamun. Penampang melintang batimetri ditunjukkan untuk dua stasiun pemijahan dan satu stasiun pembesaran (LPR1) yang terletak di barat laut Pulau Pramuka. Satu transek melintang batimetri lainnya menunjukkan adanya pematang terumbu (ridge reef) yang disebut sebagai Karang Pengantin (KPEN) oleh penduduk setempat, terletak di antara Pulau Pramuka dan Pulau Panggang.

Kecuali transek yang mengarah ke KPEN, maka beting terumbu di Pulau Pramuka tergolong broad slope yang cukup landai dengan elevasi $15-55^{\circ}$. Tanda pemijahan yang dijumpai di UPR dan SPR adalah perubahan morfologi pada ikan dewasa jantan dan betina, serta tingkah laku agresif pada ikan jantan. Taksa ikan terumbu yang menunjukkan tanda pemijahan adalah Caesionidae (UPR, SPR), Lutjanidae dan Scaridae (UPR), serta Serranidae (SPR) (Gambar 14). Sebagai bentukan 
geomorfologi yang ditengarai terkait erat dengan potensi habitat pemijahan ikan terumbu (Kobara et al. 2008), maka shelf edge dapat dijumpai di hampir seluruh transek (UPR, LPR1, dan KPEN) kecuali di SPR.
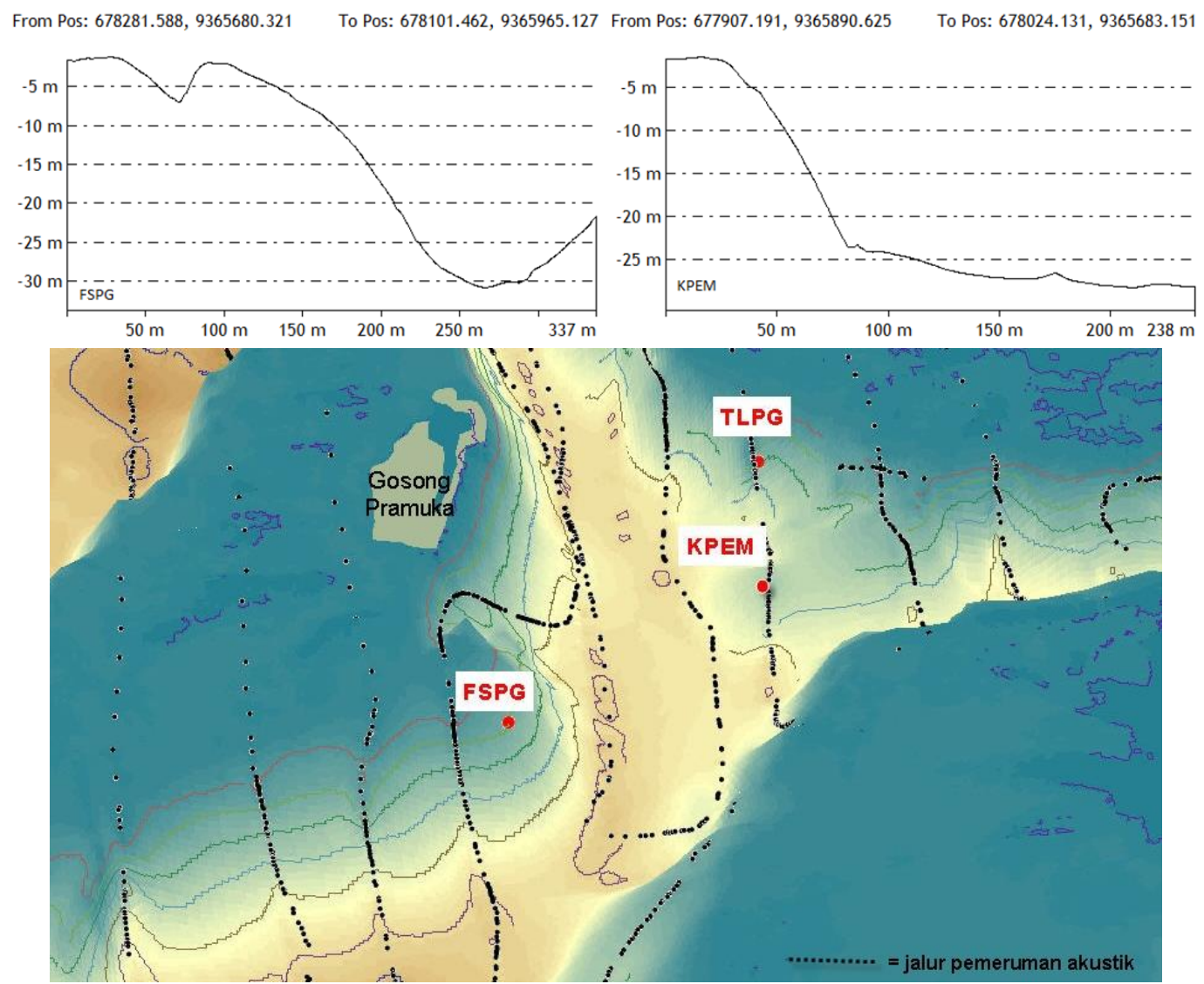

Gambar 13. Profil melintang batimetri di beting terumbu Gosong Pramuka: Fish Shelter APL Kelurahan Pulau Panggang (kiri atas), Karang Pemanggang (kanan atas), dan tampilan 3-dimensinya (bawah)
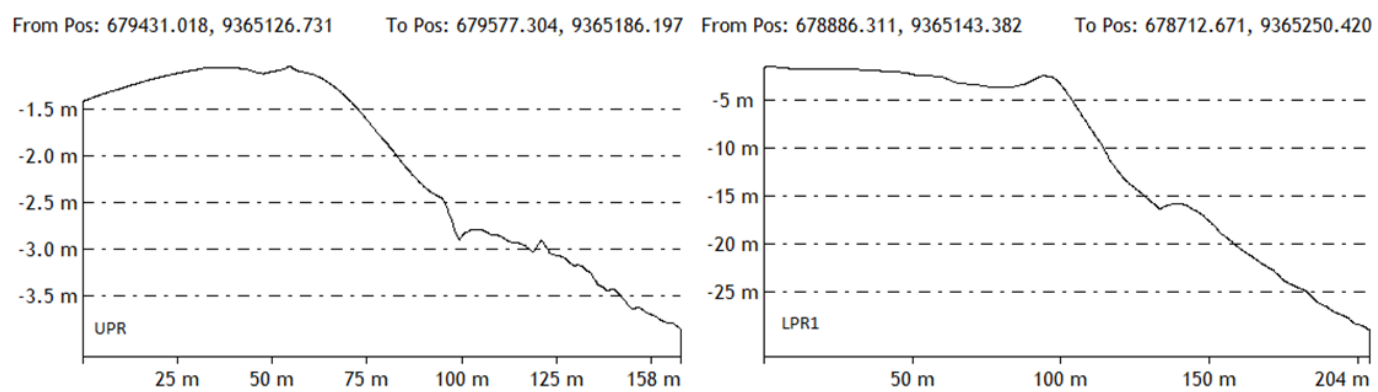

From Pos: $679083.143,9364145.842 \quad$ To Pos: $679258.567,9364039.398$ From Pos: $677897.988,9364925.737$ To Pos: $678598.496,9364793.723$
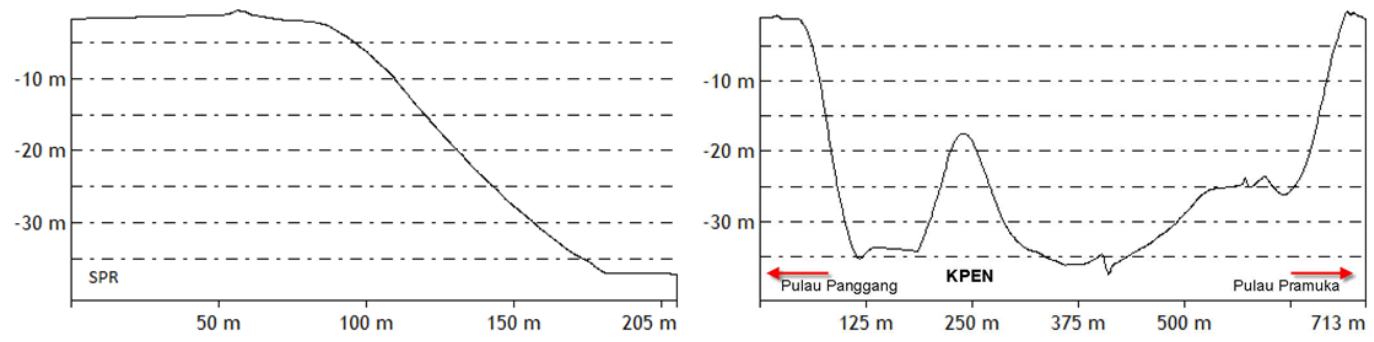

Gambar 14. Profil melintang batimetri di beting terumbu Pulau Pramuka (searah jarum jam dari kiri atas) Utara Pulau Pramuka (UPR), Stasiun Pembesaran Lamun di timur laut Pulau Pramuka (LPR1), Karang Pengantin (KPEN), dan Selatan Pulau Pramuka (SPR) 
Habitat pemijahan ikan terumbu diklasifikasikan oleh Domeier and Colin (1997) menjadi dua tipe, yaitu residen and transien. Habitat pemijahan residen menunjukkan bahwa habitat terumbu karang tersebut secara permanen digunakan oleh ikan-ikan terumbu untuk memijah berdasarkan periode tertentu, dan umumnya dimiliki oleh ikan terumbu omnivora dan herbivora. Habitat pemijahan ikan terumbu yang bersifat transien menunjukkan bahwa dalam kurun waktu non-periodik dan sulit diprediksi suatu wilayah terumbu karang berperan sebagai habitat pemijahan yang umumnya dilakukan oleh ikan predator yang memiliki kemampuan migrasi tinggi, seperti ikan kerapu (Serranidae), ikan kakap (Lutjanidae), dan lain-lain. Penetapan habitat pemijahan memerlukan monitoring in situ secara periodik dalam jangka waktu lama (2-5 tahun) yang metodenya masih terus dikembangkan, baik oleh The Nature Conservancy maupun Society for the Conservation of Reef Fish Aggregations.

\section{KESIMPULAN}

Teknologi inderaja yang mengintegrasikan sistem optik satelit dan akustik bim tunggal dapat digunakan untuk menghasilkan peta dasar perairan yang berkualitas tinggi, merujuk pada profil melintang, visualisasi 2-dimensi dan 3dimensi, serta detail bentukan geomorfologi dasar terumbu.

Dari 17 stasiun pengamatan pemijahan yang ada, maka 5 stasiun merupakan lokasi yang menunjukkan keragaan tanda pemijahan dan taksa ikan terumbu yang memiliki tanda/melakukan kegiatan pemijahan yaitu SPG, TGPG, BLPG, KPEM dan KPEN. Penilaian kondisi substrat dasar secara visual, dikombinasikan dengan fitur geomorfologi, dan keragaan taksa ikan berikut tanda pemijahan, maka secara kualitatif disarikan faktor geomorfologi yang menyokong proses awal ontogeni ikan terumbu, yaitu pemijahan.

Kegiatan pemijahan merupakan proses utama yang mendukung keberlanjutan populasi ikan terumbu, sekaligus proses ekologis penting yang perlu ditindaklanjuti identifikasi wilayahnya dalam upaya konservasi terumbu karang melalui penetapan no take zone (Daerah Perlindungan Laut).

\section{DAFTAR PUSTAKA}

Adams A.J. dan J.P. Eberson. 2009. Mechanisms Affecting Recruitment Patterns of Fish and Decapods in Tropical Coastal Ecosystems. In: Ecological Connectivity among Tropical Coastal Ecosystems. I Nagelkerken (Ed.). Springer. 185$228 \mathrm{pp}$.

Adrim M. 1997. Pengantar Studi Ekologi Komunitas Ikan Karang dan Metode Pengkajiannya dalam kursus Pelatihan Metodologi Penelitian dan Penentuan Kondisi Terumbu Karang. Puslitbang Oseanografi. LIPI. Jakarta. Hal 1-7.

Asmadin. 2011. Klasifikasi Habitat Perairan Dangkal dari Citra Satelit Quickbird Menggunakan Metode Kecerdasan Buatan. [Tesis] Sekolah Pascasarjana. Institut Pertanian Bogor.

Congalton R.G. dan K. Green. 2009. Assessing the Accuracy of Remotely Sensed Data: Principles and Practices. 2nd edition. CRC Press. 183 pp.

Domeier ML and PL Colin. 1997. Tropical reef fish spawning aggregations: defined and reviewed. Bull. Mar. Sci. 60, 698.

English S, C Wilkinson, and V Baker. 1997. Survey Manual for Tropical Marine Resources; Australian Institute of Marine Science: Townsville, QLD, Australia. 390pp.

Fonseca A.C., H.M. Guzman, J. Cortes, dan C. Soto. 2010. Marine habitat maps of Isla del Cano, Costa Rica: Comparing Quickbird and Hymap images classification results. Rev. Bol. Trop., 58 (1):373-381.

Green E.P., P.J. Mumby, A.J. Edwards, dan C.D. Clark. 2000. Remote Sensing Handbook for Tropical Coastal Management. Coastal Management Sourcebook 3. UNESCO.

http:/ / www.unesco.org/csi/pub/so urce/rs.htm [2/5/2004 10:29:26 $\mathrm{PM}]$.

Grober-Dunsmore R., S.J. Pittman, C. Caldow, M.S. Kendall, dan T.K. Frazer. 2009. A Landscape Ecology Approach for the Study of 
Ecological Connectivity Across Tropical Marine Seascapes. In: Ecological Connectivity among Tropical Coastal Ecosystems. I Nagelkerken (Ed.). Springer. 493$530 \mathrm{pp}$.

Grober-Dunsmore R, T.K. Frazer, dan W.J. Lindberg. 2007. Reef fish and habitat relationships in a Caribbean seascape: the importance of reef context. Coral Reefs 26: 201-216.

Grober-Dunsmore R., T. Frazer, dan J. Beets. 2004. The significance of adjacent habitats on reef fish assemblage structure: are relationships detectable and quantifiable at a landscape scale? Proc. Gulf Caribb. Fish. Inst., 55: 713-734.

Heyman W.D., B. Kjerfve, dan T. Ezer. 2008. Mesoamerican reef spawning aggregations help maintain fish populations:A review of connectivity research and priorities for science and management. Proc. Gulf Caribb. Fish. Inst., 59: 150-169.

Knudby, A, C. Roelfsema, M. Lyons, S. Phinn, dan S. Jupiter. 2011. Mapping Fish Community Variables by Integrating Field and Satellite Data: Object-Based Image Analysis and Modeling in a Traditional Fijian Fisheries Management Area. J Remote Sens, 1: 460-483.

Ma Z. dan R.L. Redmond. 1995. Tau coeffcients for accuracy assessment of classification of remote sensing data. Photogr Eng Remote Sensing, 61: 435-439.

Mora C. dan P. Sale. 2002. Are populations of coral reef fish open or closed? Trends Ecol. Evol., 17: 422-428.

Mumby P.J., W. Skirving, A.E. Strong, J.T. Hardy, E.F. LeDrew, E.J.
Hochberg, R.P. Stumpf, dan L.T. David. 2004. Remote sensing of coral reefs and their physical environment. Mar Poll Bull, 48: 219-228.

Mumby P.J., E.P. Green, C.D. Clark, dan A.J. Edwards. 1998. Digital analysis of multispectral airborne imagery of coral reefs. Coral Reefs, 17: 59-69.

Rahadiati A. dan S. Hartini 2007. The use of high-resolution satellite image for coral reef mapping in small island. Proceeding GeoMarine Research Forum 2007. Bakosurtanal, ISRS Jabodetabek, P4W IPB. 269-276 pp.

Russel M. 2001. Spawning Agregations of Reef Fishes on the Great Barrier Reef : Implication for Management. Great Barrier Reef Marine Park Authority. Australia. $37 \mathrm{pp}$.

Sadovy, Y. dan M. Domeier. 2005. Are aggregation-fisheries sustainable? Reef fish fisheries as a case study. Coral Reefs 24(2): 254-262.

Sadovy de Mitcheson, Y \& Colin, PL.(eds.)( 2012) Reef Fish Spawning Aggregations: Biology, Research and Management, Fish \& Fisheries Series 35: pp. 644 DOI 10.1007/978-94-007-1980-4_3, Springer Science+Business Media B.V.

Siregar V.P., S. Wouthuyzen, S. Sukimin, S.B. Agus, M.B. Selamat, Adriani, Sriati dan AA Muzaki. 2010. Informasi Spasial Habitat Perairan Dangkal dan Pendugaan Stok Ikan Terumbu Menggunakan Citra Satelit. Bogor: SEAMEO BIOTROPFPIK IPB.

Zar J.H. 1984. Biostatistical analysis, $2^{\text {nd }}$ edition. Prentice Hall. 718 pp. 
Lampiran 1. Lokasi stasiun pengamatan

\begin{tabular}{|c|c|c|c|c|}
\hline No & Kode & Keterangan & Lokasi & Pengamatan \\
\hline 1 & LPG 1 & Lamun Panggang 1 & Pulau Panggang & $\begin{array}{l}\text { P. Lamun, larva, ikan } \\
\text { juvenil }\end{array}$ \\
\hline 2 & LPG2 & Lamun Panggang 2 & Pulau Panggang & $\begin{array}{l}\text { P. Lamun, larva, ikan } \\
\text { juvenil }\end{array}$ \\
\hline 3 & LPG3 & Lamun Panggang 3 & Pulau Panggang & $\begin{array}{l}\text { P. Lamun, larva, ikan } \\
\text { juvenil }\end{array}$ \\
\hline 4 & LPG4 & Lamun Panggang 4 & Pulau Panggang & $\begin{array}{l}\text { P. Lamun, larva, ikan } \\
\text { juvenil }\end{array}$ \\
\hline 5 & LPG5 & Lamun Panggang 5 & Pulau Panggang & $\begin{array}{l}\text { P. Lamun, larva, ikan } \\
\text { juvenil }\end{array}$ \\
\hline 6 & LPG6 & Lamun Panggang 6 & Pulau Panggang & $\begin{array}{l}\text { P. Lamun, larva, ikan } \\
\text { juvenil }\end{array}$ \\
\hline 7 & LPG7 & Lamun Panggang 7 & Pulau Panggang & $\begin{array}{l}\text { P. Lamun, larva, ikan } \\
\text { juvenil }\end{array}$ \\
\hline 8 & LKR1 & Lamun Karya 1 & Pulau Karya & $\begin{array}{l}\text { P. Lamun, larva, ikan } \\
\text { juvenil }\end{array}$ \\
\hline 9 & LKR2 & Lamun Karya 2 & Pulau Karya & $\begin{array}{l}\text { P. Lamun, larva, ikan } \\
\text { juvenil }\end{array}$ \\
\hline 10 & LGSP & $\begin{array}{l}\text { Lamun Gosong } \\
\text { Pramuka }\end{array}$ & $\begin{array}{l}\text { Gosong } \\
\text { Pramuka }\end{array}$ & $\begin{array}{l}\text { P. Lamun, larva, ikan } \\
\text { juvenil }\end{array}$ \\
\hline 11 & LPR1 & Lamun Pramuka 1 & Pulau Pramuka & $\begin{array}{l}\text { P. Lamun, larva, ikan } \\
\text { juvenil }\end{array}$ \\
\hline 12 & LPR2 & Lamun Pramuka 2 & Pulau Pramuka & $\begin{array}{l}\text { P. Lamun, larva, ikan } \\
\text { juvenil }\end{array}$ \\
\hline 13 & LPR3 & Lamun Pramuka 3 & Pulau Pramuka & $\begin{array}{l}\text { P. Lamun, larva, ikan } \\
\text { juvenil }\end{array}$ \\
\hline 14 & LPR4 & Lamun Pramuka 4 & Pulau Pramuka & $\begin{array}{l}\text { P. Lamun, larva, ikan } \\
\text { juvenil }\end{array}$ \\
\hline 15 & BPG & Barat Panggang & Pulau Panggang & Karang, ikan terumbu \\
\hline 16 & BDPG & $\begin{array}{l}\text { Barat Daya } \\
\text { Panggang } \\
\end{array}$ & Pulau Panggang & Karang, ikan terumbu \\
\hline 17 & SPG & Selatan Panggang & Pulau Panggang & Karang, ikan terumbu \\
\hline 18 & TGPG & Tenggara Panggang & Pulau Panggang & Karang, ikan terumbu \\
\hline 19 & TPG & Timur Panggang & Pulau Panggang & Karang, ikan terumbu \\
\hline 20 & TLPG & $\begin{array}{l}\text { Timur Laut } \\
\text { Panggang }\end{array}$ & Pulau Panggang & Karang, ikan terumbu \\
\hline 21 & UPG & Utara Panggang & Pulau Panggang & Karang, ikan terumbu \\
\hline 22 & BLPG & Barat Laut Panggang & Pulau Panggang & Karang, ikan terumbu \\
\hline 23 & BKAR & Barat Karya & Pulau Karya & Karang, ikan terumbu \\
\hline 24 & TKAR & Timur Karya & Pulau Karya & Karang, ikan terumbu \\
\hline 25 & FSPG & $\begin{array}{l}\text { Fish Shelter Gs } \\
\text { Pramuka }\end{array}$ & $\begin{array}{l}\text { Gosong } \\
\text { Pramuka }\end{array}$ & Karang, ikan terumbu \\
\hline 26 & UPR & Utara Pramuka & Pulau Pramuka & Karang, ikan terumbu \\
\hline 27 & SPR & Selatan Pramuka & Pulau Pramuka & Karang, ikan terumbu \\
\hline 28 & KSEM & Karang Semak Daun & Semak Daun & Karang, ikan terumbu \\
\hline 29 & KKEC & Karang Keling Cetek & Keling Cetek & Karang, ikan terumbu \\
\hline 30 & KPEN & Karang Penganten & Pulau Panggang & Karang, ikan terumbu \\
\hline 31 & KPEM & Karang Pemanggang & Pulau Panggang & Karang, ikan terumbu \\
\hline
\end{tabular}

